\title{
AKTIVITAS ANTIOKSIDAN SENYAWA NON-POLAR DAN POLAR DARI EKSTRAK MAKROALGA Acanthophora muscoides DARI PANTAI KRAKAL YOGYAKARTA
}

\author{
Oleh \\ Wilis Ari Setyati ${ }^{1}$, Muhammad Zainuddin ${ }^{2}$, Rini Pramesti ${ }^{1}$ \\ ${ }^{1}$ Departemen IImu Kelautan, Universitas Diponegoro, Semarang \\ ${ }^{2}$ Program Studi Budidaya Perairan, Universitas Islam Nahdlatul Ulama, Jepara \\ Email : wilisarisetyati@yahoo.co.id \\ Received February 2017 Accepted March 2017
}

\begin{abstract}
ABSTRAK
Pantai Krakal Yogyakarta memiliki keanekaragaman rumput laut tinggi. Memiliki tipe ekologi berbatu karang yang cocok untuk habitat rumput laut jenis Acanthophora muscoides. Pemanfaatan rumput laut Pantai Krakal dalam bidang kesehatan belum optimal. Rumput laut mengandung senyawa bioaktif (polifenol) dan biopigmen (klorofil dan karotenoid) yang berfungsi sebagai antioksidan. Penelitian ini melakukan uji aktivitas antioksidan ekstrak rumput laut Acanthophora muscoides. Penelitian ini dilakukan dengan menggunakan metode eksperimen laboratoris di Laboratorium Prodi Budidaya Perairan UNISNU - Jepara. Hasil esktraksi pelarut nhexsana memiliki berat $0,471^{\mathrm{a}}$ gram dan rendemen $0,373^{\mathrm{a}} \%$, sedangkan berat ekstrak metanol $0,667^{\mathrm{b}}$ gram dan rendemen $0,529^{\mathrm{b}} \%(p<0,05)$. Nilai $\mathrm{IC}_{50}$ perlakuan ekstrak n-heksan, metanol dan vitamin c berbeda signifikan $(p<0,05)$ yaitu sebesar 312 ppm, 415 ppm dan 13 ppm, ketiganya tergolong antioksidan sangat kuat. Ekstrak n-heksan memiliki aktivitas antioksidan yang lebih baik dari pada ekstrak metanol, hal ini dikarenakan ekstrak n-heksan memiliki nilai total fenol $=45,284 \mathrm{mg}$ GAE $/ \mathrm{g}$, klorofil a $=23,299 \mathrm{mg} / \mathrm{g}$, karotenoid $=64,065 \mu \mathrm{g} / \mathrm{g}$, yang lebih tinggi dari pada ekstrak metanol yaitu total fenol $=22,235 \mathrm{mg} \mathrm{GAE} / \mathrm{g}$, klorofil a $=7,215 \mathrm{mg} / \mathrm{g}$, karotenoid $=26,654 \mu \mathrm{g} / \mathrm{g}$.
\end{abstract}

Kata kunci : makroalga, esktrak, pigmen, klorofil, karotenoid, antioksidan.

\section{ABSTRACT}

Krakal Beach Yogyakarta has a high diversity of seaweed. It has a rocky ecological type suitable for seaweed habitat type Acanthophora muscoides. Utilization of seaweed Krakal Beach in the field of health has not been optimal. Seaweed contains bioactive compounds (polyphenols) and biopigments (chlorophyll and carotenoids) that act as antioxidants. This study tested the antioxidant activity of seaweed extract Acanthophora muscoides. This research was conducted by using laboratory experimental method in Laboratory of Cultivation Study Program of UNISNU Jepara. The result of solvent extraction of $n$-hexsane had weight $0,471^{\mathrm{a}} \mathrm{gram}$ and yield $0,373^{\mathrm{a}} \%$, meanwhile weight of methanol extract $0,667^{\mathrm{b}}$ gram and rendemen $0,529^{b} \%(p<0,05)$. The value of $I_{50}$ treatment of $n$-hexane extract, methanol and vitamin $c$ was significantly different $(p<0.05)$ ie 312 ppm, 415 ppm and 13 ppm, all of which were considered very powerful antioxidants. N-hexane extract has better antioxidant activity than methanol extract, this is because n-hexane extract has total value of phenol $=45,284 \mathrm{mg} \mathrm{GAE} / \mathrm{g}$, chlorophyll $\mathrm{a}=23,299 \mathrm{mg} / \mathrm{g}$, carotenoid $=$ 
$64,065 \mu \mathrm{g} / \mathrm{g}$, more Higher than the methanol extract of total phenol $=22.235 \mathrm{mg}$ GAE / g, chlorophyll $\mathrm{a}=7,215 \mathrm{mg} / \mathrm{g}$, carotenoid $=26,654 \mu \mathrm{g} / \mathrm{g}$.

Keywords: macroalgae, extract, pigment, chlorophyll, carotenoids, antioxidants.

\section{PENDAHULUAN}

Gunung Kidul Yogyakarta terdapat Pantai Krakal yang secara geologis terkena pengaruh ombak secara langsung dari samudra Hindia. Pantai Krakal banyak ditemukan terumbu karang yang secara ekologis sebagai pemecah gelombang. Menurut Atmadja (1996) kondisi perairan tersebut cocok untuk habitat rumput laut khususnya jenis Acanthophora muscoides. Rumput laut Acanthophora muscoides belum dimanfaatkan secara maksimal (Williams, 2007). Rumput laut sangat bermanfaat misalnya di bidang kesehatan, enzimologi, dan mikrobiologi (La Barre et al., 2010). Selain itu, rumput laut juga berpotensi sebagai antitumor (Fajarningsih et al.,2008), antibakteri (Kantida et al., 2012), antifungi (Kumar et al., 2010), antivirus (Kumar et al., 2009), antifouling (Kantida et al., 2012) dan antioksidan Vijayabakar and Shiyamala (2012).

Senyawa metabolit sekunder rumput laut secara alami berpotensi sebagai antioksidan dan mempercepat reaksi oksidasi. Hal ini karena rumput laut secara ekologis mempunyai pertahanan terhadap radiasi sinar ultraviolet (Winarsi, 2007). Selain itu, rumput laut juga memiliki klorofil yang berperan dalam fotosintesis di perairan. Menurut Gill et al. (2002) adanya beberapa mikronutrien pada tumbuhan seperti vitamin A, C, E, asam folat, karotenoid (terikat dengan klorofil), antosianin, dan polifenol memiliki kemampuan menangkap radikal bebas sehingga dapat dijadikan pengganti antioksidan sintetis komersil. Antioksidan sintetis merupakan senyawa yang dapat meredam radikal bebas. Antioksidan ini tidak didapat secara alami sehingga penggunaannya harus hati-hati. Jika pemakaiannya berlebih maka fungsi antioksidan tersebut akan berubah menjadi toksik. Oleh karena itu, senyawa metabolit sekunder rumput laut tersebut perlu dikembangkan sebab penggunaan antioksidan alami tidak menimbulkan efek samping walaupun digunakan secara berlebihan (Winarno, 2004). Penelitian ini melakukan uji aktivitas antioksidan rumput laut Acanthophora muscoides pada pelarut organik non-polar dan polar.

\section{MATERI DAN METODE}

\section{Materi Penelitian}

Materi penelitian ini adalah rumput laut Acanthophora muscoides yang diambil dari lokasi sampling perairan Pantai Krakal, Gunung Kidul Yogyakarta. Sampel rumput laut Acanthophora muscoides diambil pada substrat batu karang yang terlihat saat kondisi pantai surut.

\section{Metode Penelitian}

Penelitian dilakukan dengan menggunakan metode eksperimen laboratoris. Penelitian dilaksanakan di Laboratorium Prodi Budidaya Perairan, Universitas Islam Nahdlatul Ulama Jepara. Penelitian terdiri dari 5 tahap yaitu : (1). Preparasi rumput laut (2). Ekstraksi rumput laut dengan metode maserasi dan evaporasi, (3). uji aktivitas antioksidan ekstrak rumput laut terhadap radikal DPPH, (4). Uji kandungan 
fenol ekstrak dengan metode spektrofotometri, (5). Uji kandungan pigmen klorofil a dan karotenoid dengan metode spektrofotometri.

\section{Preparasi Sampel}

Rumput laut Acanthophora muscoides yang didapat dibersihkan dengan air tawar untuk menghilangkan kotoran, pasir, lumpur dan organisme yang menempel. Acanthophora muscoides dibersihkan dengan air mengalir, menggunakan air tawar dengan beberapa kali pembilasan (3-4 kali) untuk menghilangkan kadar garam permukaan. Acanthophora muscoides yang sudah bersih ditiriskan lalu ditimbang berat basahnya. Acanthophora muscoides yang sudah bersih dilakukan pemotongan $\pm 5 \mathrm{~cm}$ hal ini dimaksutkan agar dalam penyimpanan dan penanganan sampel lebih praktis, selain itu juga memperluas bagian kontak saat proses maserasi (Manivannan et al., 2011).

\section{Ekstraksi Sampel Rumput Laut Sargassum}

Ekstraksi metabolit sekunder dilakukan dengan teknik maserasi. Sampel sebanyak 200 gram irendam menggunakan pelarut organik polar metanol $500 \mathrm{~mL}$ selama 24 jam pada suhu ruang $\pm 28{ }^{\circ} \mathrm{C}$. Selanjutnya dilakukan filtrasi menggunakan kertas saring whatman dengan corong kaca, filtrat hasil rendaman diuapkan menggunakan vacum rotary evaporator pada suhu $40{ }^{\circ} \mathrm{C}$ dengan tekanan $500 \mathrm{mbHg}$ sampai bervolume $100 \mathrm{~mL}$. Sisa hasil penguapan dilakukan partisi dengan pelarut organik non-polar n-heksan menggunakan separatory funnel sihingga didapat fraksi polar dan non-polar. Kedua filtrat diuapkan menggunakan rotary evaporator hingga didapat ekstrak. Ekstrak kemudian dihembus dengan gas $\mathrm{N}_{2}$ sebelum disimpan. Ekstrak yang diperoleh disimpan dalam freezer pada suhu $20^{\circ} \mathrm{C}$ (Kanjana et al., 2011). Berat ekstrak dihitung dengan menggunakan rumus menurut Widiarto, (2011): We $=W v_{2}-W v_{1}$, Dimana: We = berat ekstrak (gram), $\mathrm{Wv}_{1}=$ berat vial kosong (gram), $\mathrm{Wv}_{2}=$ berat vial setelah diisi ekstrak (gram).

\section{Uji Aktivitas Antioksidan}

Uji aktivitas antioksidan mengacu pada metode Miliauskas et al. (2004). Yaitu didasarkan pada kemampuan ekstrak dalam meredam radikal DPPH (2,2-diphenyl1-picrylhydrazyl). Sebanyak $3 \mathrm{ml}$ larutan DPPH 0,15 mM ditambahkan ke masingmasing 1,5 ml larutan ekstrak dengan konsentrasi 50, 150, 250, 350 dan 450 ppm sampai volume akhir $4,5 \mathrm{ml}$. Campuran reaksi dari larutan tersebut diinkubasi selama 30 menit pada suhu ruang, kemudian diukur absorbansinya menggunakan spektrofotometer UV-Visible pada panjang gelombang $517 \mathrm{~nm}$. Aktivitas antioksidan dihitung dengan menggunakan rumus :

$$
\% \text { Inhibisi }=\frac{(A-B)}{A} \times 100
$$

Keterangan : $\quad-\quad A=$ absorbansi kontrol negative larutan DPPH

$$
\text { - } \quad B=\text { absorbansi ekstrak dan DPPH }
$$

Nilai \% inhibisi digunakan untuk menentukan nilai $\mathrm{IC}_{50}$ dengan menggunakan analisis regresi linier sederhana.

\section{Uji Kadar Total Fenol}

Uji kadar total fenol dilakukan menurut Yangthong et al. (2009) yaitu menggunakan standar asam galat. Larutan standar asam galat pada konsentrasi 0 , 
10, 20, 30, 40, 50, 60, dan 70 mg/l. Masing-masing ekstrak 5 mg dilarutkan dalam 2 $\mathrm{ml}$ etanol. Larutan ditambahkan $5 \mathrm{ml}$ aquadest dan $0,5 \mathrm{ml}$ reagen Folin-Ciocalteau $50 \%(\mathrm{v} / \mathrm{v})$. Campuran didiamkan selama 5 menit kemudian ditambahkan $1 \mathrm{ml}$ $\mathrm{Na} 2 \mathrm{CO} 35 \%(\mathrm{~b} / \mathrm{v})$. Campuran dihomogenkan lalu diinkubasi dalam kondisi gelap selama satu jam. Absorbansi yang dihasilkan diukur dengan spektrofotometer UVVisible pada panjang gelombang $725 \mathrm{~nm}$. Nilai total fenol rumput laut Acanthophora muscoides dinyatakan dalam "mg Galic Acid Equivalent (GAE)/ g ekstrak".

$$
\text { Total Fenol }=\frac{(a \times V) / 1000 \mathrm{ml}}{G}
$$

Keterangan : a = konsentrasi asam galat dalam sampel uji (mg/tt)

$\mathrm{V} \quad=$ volume total larutan uji $(\mathrm{ml})$

$\mathrm{G} \quad=$ jumlah ekstrak yang ditimbang $(\mathrm{g})$

$1000 \mathrm{ml}=$ faktor konversi terhadap volume total larutan $(\mathrm{ml})$

\section{Uji Kadar Klorofil a dan Karotenoid}

Pengukuran klorofil a dan karotenoid berdasarkan Lichtenthaler (1987). Ekstrak rumput laut Acanthophora muscoides dari tiap pelarut ditimbang sebanyak 5 mg, kemudian dilarutkan dengan aseton $80 \%$ dengan konsentrasi $5 \mathrm{mg}$ ekstrak/5 ml aseton $80 \%$. Masing-masing konsentrasi diukur absorbansinya pada panjang gelombang $646 \mathrm{~nm}, 663 \mathrm{~nm}$, dan $470 \mathrm{~nm}$. Kadar klorofil dan karotenoid dihitung berdasarkan rumus sebagai berikut:

i. Klorofil a $=12,21 \times \mathrm{A}_{663}-2,81 \times \mathrm{A}_{646}$

ii. Karotenoid $=\frac{(A 470+0,114 \times A 663-0,638 \times A 646) \times V \times 1000}{}$

$112,5 \times 0,1 \times 10$

Keterangan : A470, A663, A646, A638 : Nilai absorbansi pada 470,663,646,638 nm $\mathrm{V}$ : Volume ekstrak (ml).

\section{HASIL DAN PEMBAHASAN}

Sampling rumput laut telah dilakukan di Pantai Krakal Gunung Kidul Yogyakarta. Sampel rumput laut dilakukan preparasi (pembersihan dan pemotongan) dan selanjutnya ekstraksi dengan teknik maserasi. Esktraksi menggunakan dua jenis pelarut yaitu pelarut organik non-polar $n$ heksana dan polar metanol. Berdasarkan gambar 1 (a) menunjukkan bahwa perlakuan perbedaan pelarut mempengaruhi nilai berat ekstrak secara signifikan $(p<0,05)$. Esktrak pelarut $n$ - hexsana memiliki nilai berat $0,471^{a}$ gram sedangkan berat ekstrak pelarut metanol lebih tinggi $41,67 \%$ yaitu dengan nilai $0,667^{\mathrm{b}}$ gram. Berdasarkan gambar 1 (b) menunjukkan bahwa perlakuan perbedaan pelarut mempengaruhi nilai rendemen secara signifikan $(p<0,05)$. Esktrak pelarut $n$ - hexsana memiliki nilai rendemen $0,373^{\mathrm{a}} \%$ sedangkan rendemen ekstrak metanol lebih tinggi $42,11 \%$ yaitu dengan nilai $0,529^{\mathrm{b}} \%$. Perbedaan hasil ekstraksi diduga karena perbedaan polaritas pelarut yang digunakan. Sarastani et al. (2002), ekstraksi menggunakan pelarut dengan polaritas berbeda dapat menghasilkan ekstrak dengan polaritas yang berbeda pula sesuai dengan sifat kepolaran masing-masing ekstrak. 

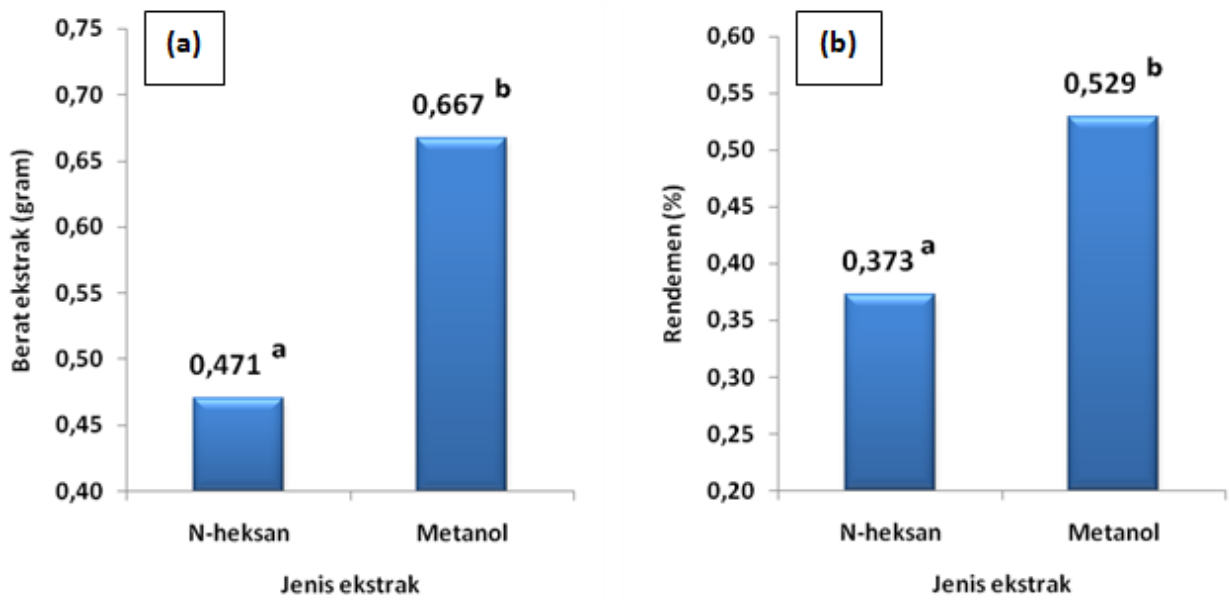

Gambar 1. Data preparasi sampel (a) Berat ekstrak dan (b) Rendemen (\%).

Ekstrak masing - masing pelarut selanjutnya dilakukan uji aktivitas antioksidan terhadap radikal bebas DPPH. Berdasarkan gambar 2 menunjukkan bahwa perlakuan perbedaan konsentrasi ekstrak rumput laut Acanthophora muscoides pelarut $\mathrm{n}$-heksan memberikan nilai inhibisi yang berbeda signifikan $(p<$ $0,05)$.

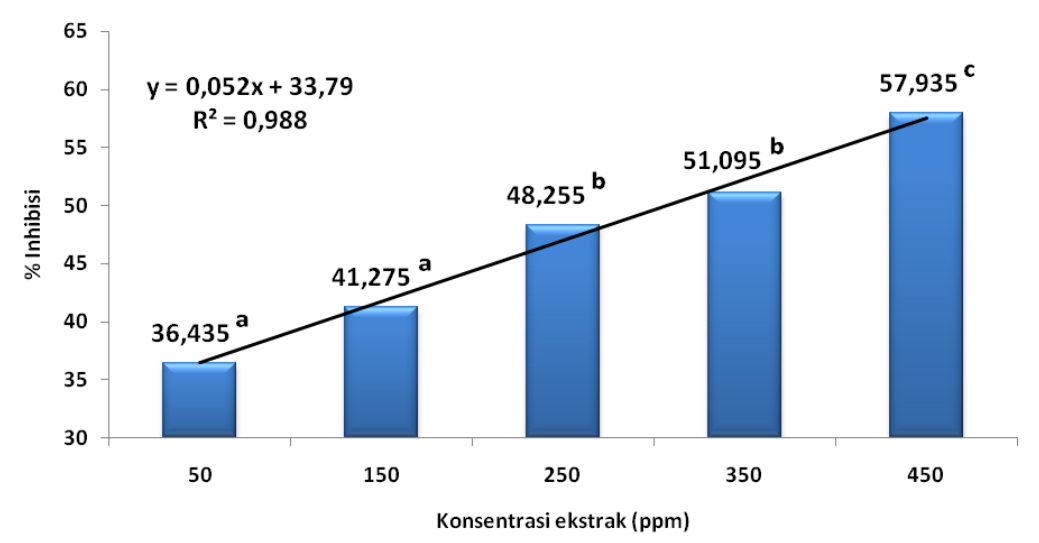

Gambar 2. Regresi linier perbedaan konsentrasi ekstrak n-heksan terhadap \% inhibisi.

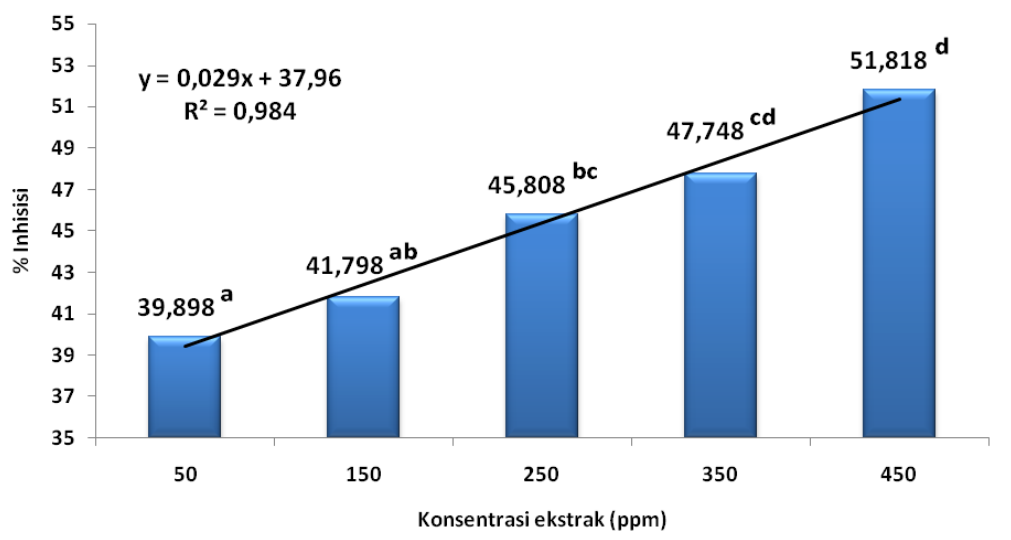

Gambar 3. Regresi linier perbedaan konsentrasi ekstrak metanol terhadap \% inhibisi. 


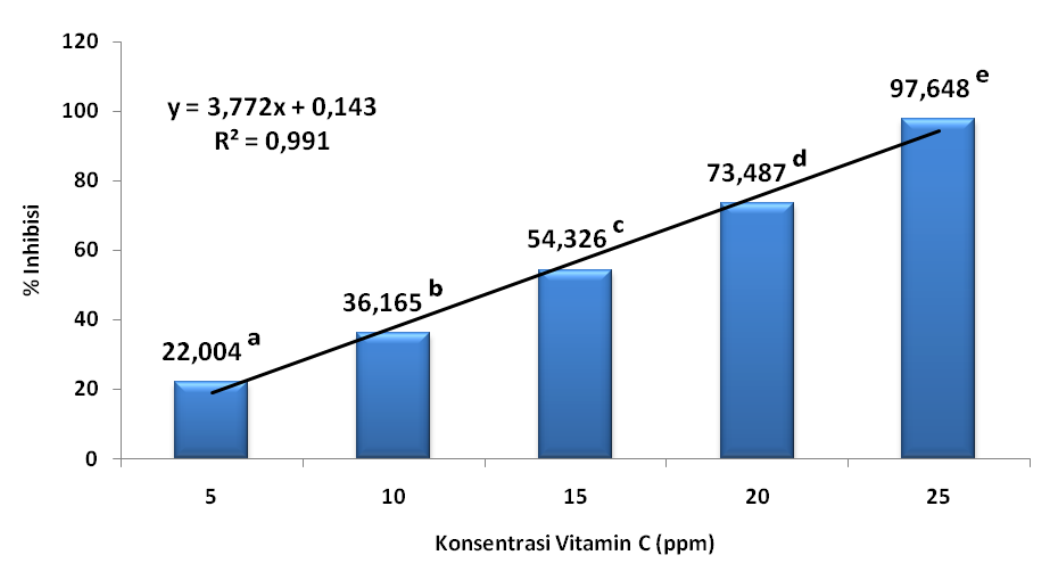

Gambar 4. Regresi linier perbedaan konsentrasi vitamin c terhadap \% inhibisi.

Data \% inhibisi menunjukkan berpola linier yaitu semakin tinggi konsentrasi ekstrak 50, 150, 250, 350 dan 450 ppm maka nilai persen inhibisi semakin tinggi yaitu sebesar $36,435^{\mathrm{a}} ; 41,275^{\mathrm{a}} ; 48,255^{\mathrm{b}} ; 51,095^{\mathrm{b}}$ dan $57,935^{\mathrm{c}}$ dengan persamaan linier $y=0,052 x+33,79$ dan koefisien determinan sebesar 0,988 . Semakin besar konsentrasi ekstrak warna ungu pada DPPH semakin pudar menjadi kuning. Hasil penelitian Andayani et al. (2008) menyatakan bahwa pada konsentrasi yang lebih tinggi akan menunjukkan aktivitas antioksidan yang lebih tinggi. Menurut Kim (2005), ketika radikal DPPH bereaksi dengan suatu senyawa antioksidan maka DPPHakan tereduksi menjadi DPPH-H. Kapasitas penangkapan radikal bebas ditunjukkan dengan persentase berkurangnya warna ungu dari DPPH.

Perlakuan perbedaan konsentrasi ekstrak rumput laut Acanthophora muscoides pelarut metanol (gambar 3) memberikan nilai inhibisi yang berbeda signifikan $(p<0,05)$. Distribusi data \% inhibisi menunjukkan berpola linier yaitu semakin tinggi konsentrasi ekstrak 50, 150, 250, 350 dan 450 ppm maka nilai persen inhibisi semakin tinggi yaitu sebesar $39,898^{\mathrm{a}} ; 41,798^{\mathrm{ab}} ; 45,808^{\mathrm{bc}} ; 47,748^{\mathrm{cd}}$ dan $51,818^{d}$ dengan persamaan linier $y=0,029 x+37,96$ dan koefisien determinan sebesar 0,984. Hasil penelitian menunjukkan ekstrak mengandung senyawa antioksidan dan senyawa ini menyumbang atom $\mathrm{H}$ kepada radikal bebas DPPH sehingga radikal DPPH menjadi lebih stabil yang ditunjukkan dengan adanya perubahan warna dari ungu menjadi kuning. Sesuai dengan pendapat Molyneux (2004), perubahan warna terjadi karena adanya reaksi antara molekul DPPH dengan molekul atom $\mathrm{H}$ yang dilepaskan oleh molekul komponen bahan uji (senyawa antioksidan), sehingga terbentuk senyawa DPPH yang berwarna kuning.

Penelitian ini melakukan uji aktivitas antioksidan menggunakan kontrol positif vitamin c. Perlakuan perbedaan konsentrasi vitamin c (gambar 4) memberikan nilai inhibisi yang berbeda signifikan $(p<0,05)$. Terdapat hubungan antara konsentrasi dan \% inhibisi yaitu hubungan linier semakin tinggi konsentrasi vitamin c 50, 150, 250, 350 dan 450 ppm maka nilai persen inhibisi semakin tinggi yaitu sebesar $22,004^{\text {a }} ; 36,165^{\text {b }} ; 54,326^{\text {c }} ; 73,487^{\text {d }}$ dan $97,648^{\mathrm{e}}$ dengan persamaan linier $y=3,772 x$ $+0,143$ dan koefisien determinan sebesar 0,991 . 


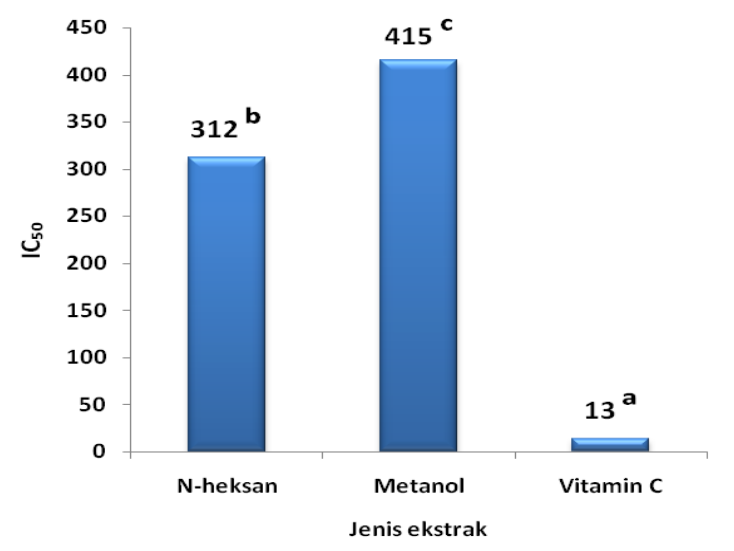

Gambar 5. Nilai $\mathrm{IC}_{50}$ pada ekstrak n-heksan, metanol dan vitamin c.

Berdasarkan persamaan linier dari tiap perlakuan maka selanjutnya dilakukan penentuan nilai $I C_{50}$. Nilai $I C_{50}$ ketiga perlakuan (ekstrak n-heksan, ekstrak metanol dan vitamin c) disajikan pada gambar 5. Hasil uji one way anova perlakuan memiliki nilai $\mathrm{IC}_{50}$ berbeda secara signifikan $(p<0,05)$ dimana ekstrak $\mathrm{n}$-heksan memiliki aktivitas antioksidan yang lebih baik dari pada ekstrak metanol. Berdasarkan gambar 5 menunjukkan bahwa Nilai $\mathrm{IC}_{50}$ perlakuan ekstrak n-heksan sebesar 312 ppm dengan kriteria tergolong sebagai antioksidan sagat kuat. Perlakuan ekstrak metanol memiliki $I_{50}$ sebesar 415 ppm dengan kriteria tergolong sebagai antioksidan sagat kuat. Perlakuan vitamin $\mathrm{c}$ memiliki nilai $\mathrm{IC}_{50}$ yang paling rendah yaitu sebesar 13 ppm dengan kriteria tergolong sebagai antioksidan sagat kuat. Perbedaan nilai $\mathrm{IC}_{50}$ pada ekstrak diduga karena perbedaan polaritas pelarut. Menurut Ismail et al. (2002), aktivitas antioksidan sangat tergantung pada jenis pelarut yang digunakan karena senyawa dengan polaritas yang berbeda menunjukkan tingkat aktivitas antioksidan yang berbeda pula.

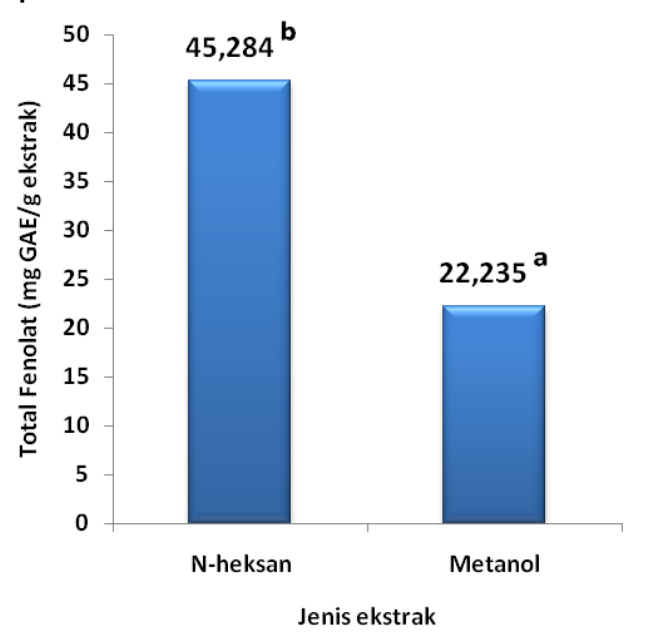

Gambar 6. Nilai total fenolat pada ekstrak n-heksan dan metanol. 

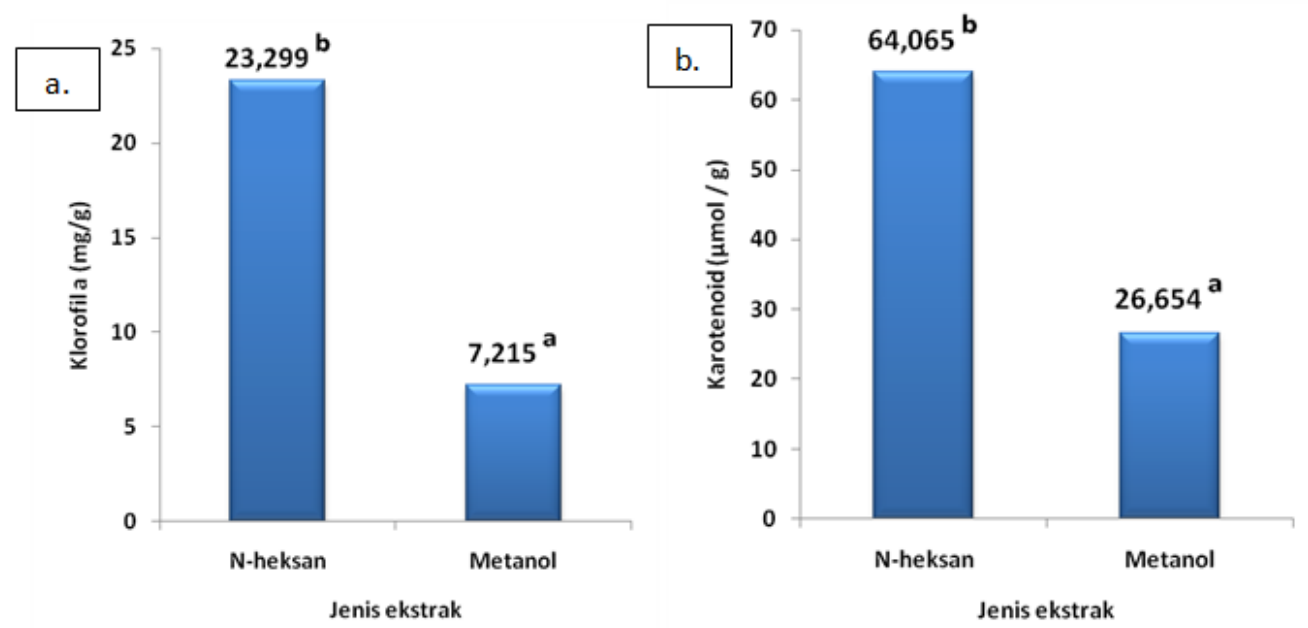

Gambar 7. Kadar pigmen klorofil a dan karotenoid pada ekstrak n-heksan dan metanol.

Aktivitas antioksidan ekstrak Acanthophora muscoides diduga terjadi karena terdapat komponen senyawa fenol, klorofil a dan karotenoid. Oleh sebab itu, dilakuka uji kadar total fenolik, klorofil a dan total karotenoid untuk mengetahui potensinya sebagai antioksidan. Data total fenol (gambar 6) menunjukkan bahwa kandungan senyawa fenol pada kedua ekstrak adalah berbeda secara signifikan ( $p$ $<0,05)$. Ekstrak rumput laut pelarut $n$-heksan memiliki nilai total fenol sebesar 45,284 $\mathrm{mg} \mathrm{GAE} / \mathrm{g}$ yang lebih tinggi signifikan 103,66 \% dari pada total fenol ekstrak rumput laut pelarut metanol 22,235 mg GAE/g. Sheikh et al. (2009) senyawa fenolik terbanyak tidak selalu terdapat dalam ekstrak polar, namun tergantung dari struktur senyawa fenolik yang terkandung. Hasil penelitian yang dilakukan menunjukkan kadar total fenol ekstrak heksana dari Sargassum baccularia lebih tinggi dibandingkan ekstrak metanolnya.

Selain total fenol juga dilakukan analisis kadar pigmen klorofil a dan karotenoid yang disajikan pada gambar 7. Data kadar klorofil a pada gambar 7 (a) menunjukkan bahwa kandungan klorofil a pada kedua ekstrak adalah berbeda secara signifikan $(p<0,05)$. Ekstrak Acanthophora muscoides pelarut $\mathrm{n}$-heksan memiliki nilai klorofil a sebesar 23,299 mg/g yang lebih tinggi signifikan 222,93 \% dari pada klorofil a ekstrak Acanthophora muscoides pelarut metanol 7,215 mg/g. Selanjutnya data kadar karotenoid pada gambar 7 (b) menunjukkan bahwa kandungan karotenoid pada kedua ekstrak adalah berbeda secara signifikan ( $p<$ 0,05). Ekstrak Acanthophora muscoides pelarut $n$-heksan memiliki nilai karotenoid sebesar 64,065 $\mathrm{\mu g} / \mathrm{g}$ yang lebih tinggi signifikan 140,36 \% dari pada karotenoid ekstrak Acanthophora muscoides pelarut metanol 26,654 $\mu \mathrm{g} / \mathrm{g}$. Masojidek et al. (2004) menyatakan klorofil termasuk pigmen non-polar dan harus diekstrak dengan pelarut organik. Reaksi karotenoid terhadap radikal bebas ditunjukkan oleh $\beta$ karoten yang bereaksi dengan radikal peroksil dapat mengakibatkan terbentuknya radikal ROO-Carotene (radikal ROO-CAR) dan terjadi delokasi elektron, sehingga elektron tersebar di seluruh struktur $\beta$-karoten. Radikal ROO-CAR yang bereaksi dengan radikal $\mathrm{ROOR}-\mathrm{CAR}$ dapat membentuk $\beta$-karoten netral. 


\section{KESIMPULAN}

Berdasarkan data $\mathrm{IC}_{50}$, kadar klorofil a dan karotenoid maka dapat diketahui bahwa ekstrak rumput laut Acanthophora muscoides pelarut n-heksan memiliki aktivitas antioksidan yang paling tinggi. Pelarut $n$-heksan lebih baik dari pada metanol dalam fungsi ekstraksi senyawa antioksidan pada rumput laut Acanthophora muscoides.

\section{UCAPAN TERIMAKASIH}

Penulis mengucapkan terimakasih kepada LPPM UNISNU Jepara yang telah mensuport dalam penelitian kerjasama dengan UNDIP Semarang. Selain itu juga, mengucapkan terimakasih kepada Ka Prodi Budidaya Perairan UNISNU Jepara atas kesempatan yang diberikan kepada penulis untuk dapat mengerjakan penelitian ini.

\section{DAFTAR PUSTAKA}

Andayani, R., Lisawati, Y., danMaimunah. 2008. Penentuan aktivitas antioksidan, kadar fenolat total dan likopen pada buah tomat (Solanum lycopersicum L). Jurnal Sains dan Teknologi Farmasi. 13(1): 1-9.

Atmadja W.S; Kadi,A; Sulistijo; Rachmaniar. 1996. Pengenalan Jenis-Jenis Rumput Laut Indonesia. Puslitbang Oseanologi-LIPI. Jakarta

Fajarningsih, N. D., M. Nursid, T. Wikanta dan E. Marraskuranto. 2008. Bioaktivitas Ekstrak Turbinaria decurrens sebagai Antitumor (HeLadan T47D) serta Efeknya terhadap Proliferasi Limfosit. Jurnal Pascapanen dan Bioteknologi Kelautan dan Perikanan 3 (1) : 21-27.

Gill, A. M., R.A. Bradstock, J.E. Williams. 2002. Fire Regimes And Biodiversity: Legacy And Vision. In: Flammable Australia: The Fire Regimes and Biodiversity of a Continent (eds. R. Bradstock, J.E. Williams, A. Malcolm Gill): 429-446.

Ismail, J., Runtuwene M. R. J.,\&Fatimah, F. 2002. Penentuan Total Fenolik Dan UjiAktivitasAntioksidanPadaBiji Dan KulitBuah Pinang Yaki (Areca VestiariaGiseke).Program Studi Kimia, FakultasMatematikadanllmuPengetahuanAlam, Universitas Sam Ratulangi. Manado.

K Manivannan, G devi Karthikai, P Anantharaman, T Balasubramanin, 2011. Antimicobial potential of selected brown seaweeds from Vedalai coastal waters, Gulf of Mannar. Asian Pasific Journal of Tropical Biomedicine, 114120.

Kanjana Kulwadee, Radtanatip Tawut, Asuvapongpatana Somluk, Withyachumnarnkul Boonsirm, Kanokpan Wongprasert. 2011. Solvent extracts of the red seaweed Gracilaria fisheri prevent Vibrio Harveyi infections the black tiger shrimp Panaeus monodon. Fish \& Shellfish Immunology 30 (2011) 389-396.

Kantida, S. R., K. R. T. Asha and S. Sujatha. 2012. Influence of Bioactive Compounds of Seaweeds and Its Biocidal and Corrotion Inhibitory Effect of Mild Steel. Research Journal of Environmental Toxicology, 6 (3) : 101-109.

Kim, O.S. 2005. Radical scavenging capacity and antioksidant activity of the $E$ vitamer fraction in rice bran. Journal of Food Science. 70(3): 208-213. 
Kumar, R. R., J. K. Patterson, dan M. Jaikumar. 2010. Macro Benthic Community Structure on Tuticorin Coastal Waters Gulf of Mannar, South East Coast of India. World Journal of Fish and Marine Sciences. 2(1). 70-77.

Kumar, S. S., Y. Kumar, M. S. Y. Khan, J. Anbu and E. De Clercq. 2009. Antihistaminic, Anticholinergic and Antiviral Activities of Fucosterol from Turbinaria conoides (J. Agardh) Kutzing. Pharmacologyonline, 1 : 11041112.

La Barre, S., P. Potin, C. Leblanc and L. Delage. 2010. The Halogenated Metabolism of Brown Algae (Phaeophyta), Its Biological Importance and Its Environmental Significance. Marine Drugs, 8 : 988-1010.

Lichtenthaler. H. K. 1987. Clorophylls and Carotenoids: Pigments of Photosynthetic Biomembranes Methods in Enzymology. Weinheim : Verlag Chemie.

Masojidek, J., M. Koblizek, \& G. Torzillo. 2004.Photosynthesis in microalgae in: A. Richmond(Ed). Handbook of Microalgal Culture:Biotechnology and Applied Phycology. BlakwellScience Ltd., lowa. p.20-39.

Miliauskas, G., Venskutonis, P. R., \& Van Beek, T. A. (2004). Screeningof radical scavenging activity of some medicinal and aromatic plant extracts. Food Chemistry : 85, 231-237.

Molyneux P. 2004. The use of stable free radical diphenylpicrylhydrazyl (DPPH) for estimating antioksidan activity. Songklanakarin J Sci Technol. 26(2):211219.

Sarastani, D, Soekarto S, Muchtadi T, Fardiaz D, Apriyantono A. 2002. AktivitasAntioksidanEkstrakdanFraksiEkstrakBijiAtung

(ParinariumglaberrimumHassk).JurnalTeknologidanIndustriPangan. Volume XIII Nomor 2.

Sheikh TZB, Yong CL, and Lian MS. 2009. In vitro antioxidant activity of the hexane and methanolic extracts ofSargassum baccularia and Cladophora patentiramea. Journal of Applied Sciences. 13(9): 2490-2493.

Vijayabaskar, P. Vaseela. N. Thirumaran G. 2012. Potential antibacterial and antioxidant properties of a sulfated polysaccharide from the brown marine algae Sargassum swartzii. Chinese Journal of Natural Medicines 2012, 10(6): 0421-0428

Widiarto E., 2011. Aplikasi Bakteri Simbion Gastropoda sebagai Antibakteri dalam Bentuk Sediaan Gel Antiseptik Tangan. [Skripsi]. Fakultas Perikanan dan IImu Kelautan UNDIP Semarang.

Williams, A. M. 2007. Analysis of Benefits of Sargassum on Galveston Island and Indications for Beach Management Policy. [Thesis]. Graduate Studies of Texas A \& M University. Texas. USA.

Winarno, F.G. 2004. Kimia PangandanGizi. PT. GramediaPustakaUtama. Jakarta.

Winarsi H.2007. Antioksidan Alami dan Radikal Bebas. Kanisius, Yogyakarta.

Yangthong M, Nongporn HT, Phromkunthong W. 2009. Antioxidant Activities Of Four Edible Seaweeds From The Southern Coast Of Thailand. Plant Foods Human Nutrition. 64 : 218-223. 